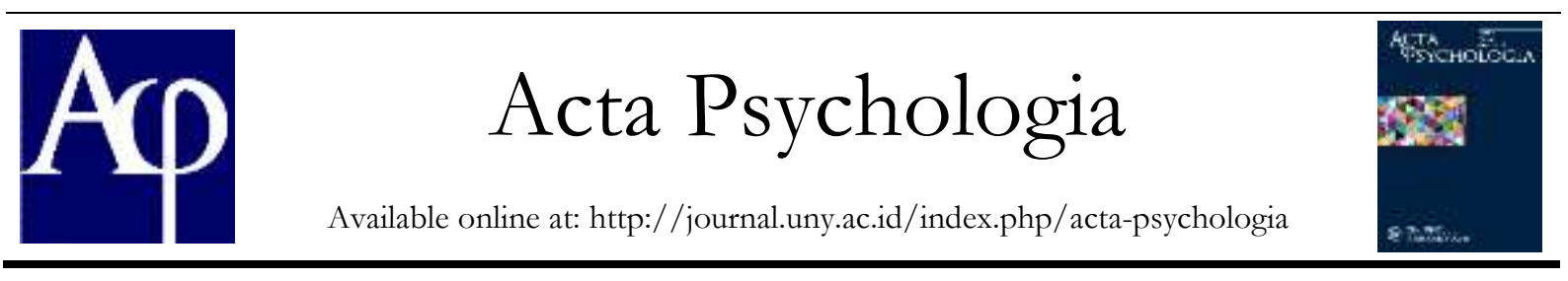

\title{
Dukungan Sosial Teman Sebaya Sebagai Prediktor Psychological Well- Being pada Remaja
}

\author{
Asifa Mufidha \\ Jurusan Psikologi, Fakultas Ilmu Pendidikan, Universitas Negeri Yogyakarta; \\ Jl. Colombo No. 1 Sleman Yogyakarta, 55281 \\ amufidha@gmail.com
}

\begin{abstract}
Abstrak
Penelitian ini bertujuan untuk mengetahui pengaruh dukungan sosial dari teman sebaya terhadap psychological wellbeing pada remaja. Pendekatan penelitian ini menggunakan pendekatan kuantitatif desain korelasional. Penelitian dilakukan di SMP IT Masjid Syuhada. Sampel diambil menggunakan teknik acak sederhana dan mendapatkan 163 siswa. Pengumpulan data dilakukan dengan menyebarkan 2 kuesioner, yaitu Skala Psychological Well-Being dan Skala Dukungan Sosial Teman Sebaya. Teknik analisis yang digunakan adalah analisis deskriptif dan analisis regresi linear. Hasil penelitian menunjukkan bahwa terdapat pengaruh positif dukungan sosial teman sebaya terhadap psychological well-being pada remaja dengan $\mathrm{r}=0.651, \mathrm{R}^{2} 0.424, \mathrm{p}<0.001$. Variabel dukungan sosial teman sebaya berkontribusi sebanyak $42.4 \%$ terhadap psychological well-being pada remaja. Sumbangan tertinggi adalah dimensi hubungan yang positif dengan orang lain, yaitu sebesar $35.77 \%$ dan sumbangan terendah adalah dimensi tujuan hidup sebesar $9.27 \%$.
\end{abstract}

Kata Kunci: dukungan sosial teman sebaya, psychological well-being

\begin{abstract}
This research aims to examine the effect of peer social support on psychological well-being in adolescents. This research used quantitative approach with correlational design. This study conducted in SMP IT Masjid Syuhada Yogyakarta. Sample was taken using simple random sampling technique and obtained 163 students. Data was collected using questionaries, namely Psychological Well-Being Scale and Peer Social Support Scale. Data was analyzed by descriptive analysis and linear regression analysis. The results of this study showed that there were positive effect from peer social support on psychological well-being in adolescents with $\mathrm{r}=0.651, \mathrm{p}<0.001$. Variables of peer social support contributed $42.4 \%$ to psychological well-being in adolescents. The highest dimension contribution was positive relation with others $(35.77 \%)$ and the lowest contribution was purpose in life dimension $(9.27 \%)$.
\end{abstract}

Keywords: peer social support, psychological well-being

\section{Pendahuluan}

Masa remaja merupakan periode transisi perkembangan antara masa kanakkanak dan masa dewasa yang dimulai pada sekitar usia 10 hingga 12 tahun dan berakhir pada usia sekitar 18 hingga 22 tahun (Santrock, 2012). Berdasarkan Teori Perkembangan dari Erikson (dalam Santrock, 2012), masa remaja berada pada tahap psikososial yang sangat penting yaitu pembentukan identitas (identity formation).
Harapannya pada masa ini remaja dapat menemukan identitas dirinya. Jika remaja gagal menemukan identitas dirinya maka mereka akan mengalami kebingungan identitas dan ketidakpuasan dalam dirinya. Hal itu akan menyebabkan munculnya perilaku menyimpang (deliquent), melakukan tindakan kriminalitas, dan mengganggu masyarakat sekitar (Batubara, 2017). 
Tindakan kriminalitas yang dilakukan oleh remaja seringkali meresahkan dan merugikan masyarakat (Batubara, 2017). Dalam kurun waktu tiga tahun terakhir yaitu dari tahun 2016-2018 diperoleh data statistik Komisi Perlindungan Anak Indonesia (KPAI) terkait kasus kriminalitas remaja yang mengalami peningkatan, antara lain kasus tawuran pelajar, bullying di sekolah, kekerasan fisik, kekerasan psikis, kekerasan seksual, kecelakaan lalu lintas, penggunaan NAPZA, pengedar NAPZA, pembunuhan, pencurian, dan kepemilikan senjata tajam. Begitu pula yang terjadi di Yogyakarta, terdapat banyak kasus kriminalitas yang dilakukan oleh remaja seperti tawuran pelajar dan klithih (Sucahyo, 2017).

Permasalahan-permasalahan tersebut akan mempengaruhi remaja dalam menyelesaikan tahap perkembangan dan mencapai kesejahteraan (Santrock, 2007). Pada setiap tahap perkembangan manusia, individu memiliki tugas perkembangan yang harus dilakukan, tidak terkecuali pada remaja. Menurut Havighurst (dalam Putra \& Ramdani, 2014) tugas perkembangan merupakan tugas- tugas yang harus diselesaikan individu pada fase- fase atau periode kehidupan tertentu. Apabila individu berhasil menyelesaikan tugas perkembangannya, maka individu akan merasa bahagia dan puas, tetapi sebaliknya apabila individu gagal dalam menyelesaikan tugas perkembangannya, maka individu akan merasa kecewa dan akan mengalami hambatan pada tahap perkembangan selanjutnya. Begitu pula dengan remaja, pencapaian tahap perkembangan dapat berbeda antara remaja yang satu dengan remaja yang lainnya. Ada remaja yang dapat mencapai tahap perkembangan dengan baik, namun ada pula remaja yang lamban atau mengalami hambatan dalam mencapai tahap perkembangannya (Batubara, 2017).

Remaja akan dapat mencapai tahap perkembangannya, apabila remaja memiliki psychological well-being yang baik (Batubara, 2017). Psychological well-being merupakan sebuah konsep yang berusaha memaparkan kesehatan psikologis individu berdasarkan pemenuhan fungsi psikologis secara positif atau disebut dengan positive psychological functioning (Ryff, 1989). Psychological wellbeing merupakan suatu pencapaian penuh dari potensi psikologis seseorang dan suatu kondisi dimana seseorang dapat menerima kekuatan dan kelemahan dirinya, memiliki tujuan hidup, mengembangkan relasi yang positif dengan orang lain, menjadi pribadi yang mandiri, mampu mengendalikan lingkungan, dan berkembang secara personal (Ryff, 1989).

Berdasarkan hasil observasi pada tanggal 20 Februari 2018 dan wawancara pada tanggal 10 Oktober 2018 yang dilakukan peneliti di SMP IT Masjid Syuhada Yogyakarta disimpulkan bahwa siswa-siswi SMP IT Masjid Syuhada Yogyakarta memiliki tingkat psychological wellbeing yang berbeda. Perbedaan tersebut disebabkan karena terdapat beberapa faktor yang berperan penting dalam psychological well-being pada remaja, yaitu status sosial ekonomi, dukungan sosial, religiusitas, dan kompetensi remaja (Liputo dalam Batubara 2017).

Salah satu faktor yang mempengaruhi psychological well-being adalah dukungan sosial (Ginting, 2015). Dukungan sosial yang diterima oleh individu dari lingkungan yang berupa semangat, perhatian, penghargaan, bantuan dan kasih sayang akan membuat remaja menganggap bahwa dirinya dicintai, diperhatikan, dan dihargai oleh orang lain (Ginting, 2015). Dukungan sosial dapat diperoleh dari pasangan, anak-anak, anggota keluarga yang lain, teman, professional, komunitas atau masyarakat dan kelompok sosial lainnya (Taylor dalam Indrawati, 2017). Individu yang mendapatkan dukungan sosial akan merasa diterima dan dihargai secara positif. Dengan begitu individu akan cenderung mengembangkan sikap positif terhadap dirinya sendiri, lebih menerima dan menghargai dirinya sendiri, serta dapat merealisasikan potensi yang ada dalam 
dirinya sehingga individu dapat mencapai psychological well-being (Ginting, 2015). Sebaliknya, ketiadaan dukungan sosial atau pertemanan yang berarti pada masa remaja akan menyebabkan penyesuaian psikologis yang rendah dan meningkatkan risiko masalah-masalah psikologis pada masa dewasa (Seymour, 2017).

Dukungan sosial mengacu pada kenyamanan, perhatian, harga diri, atau bantuan tersedia bagi seseorang dari orang atau kelompok lain (Uchino dalam Sarafino \& Smith, 2011). Dukungan sosial juga mengacu pada perasaan seseorang atau persepsi bahwakenyamanan, perhatian, dan bantuan tersedia jika diperlukan — yaitu dukungan yang dirasakan (Sarafino dan Smith, 2011). Dukungan yang diberikan secara langsung dan berwujud, memberikan rasa aman dan nyaman, memberikan penghargaan yang positif, dan memberikan penilaian berupa nasihat, saran ataupun umpan balik mengenai apa yang sebaiknya dilakukan akan membentuk dukungan sosial (Cohen \& Syme dalam Indrawati, 2017).

Remaja lebih banyak berinteraksi dengan teman sebayanya (Santrock, 2012). Dibandingkan pada masa kanak-kanak, remaja awal lebih banyak menyesuaikan diri terhadap standar teman sebaya. Remaja menganggap bahwa teman sebaya sebagai sesuatu yang mampu memberikan dunia bagi orang-orang muda untuk melakukan perkembangan sosialnya, nilai-nilai yang berlaku bukanlah nilai-nilai yang ditetapkan dari orang dewasa melainkan dari temantemannya.

Remaja menghabiskan banyak waktu dengan teman sebayanya melebihi waktu dengan orang tua dan anggota keluarga lain, waktu mereka cukup banyak tersita untuk berpacaran atau berpikir mengenai pacaran (Collinz, Welsh, dan Furman; Conolly dan McIsaac dalam Santrock, 2012).

Terkait relasi pertemanan antar siswa, peneliti melakukan wawancara dengan Guru BK SMP IT Masjid Syuhada Yogyakarta pada hari Jumat, 23 maret 2018.
Guru BK mengatakan bahwa siswi perempuan cenderung lebih mempermasalahkan relasi pertemanan maupun persahabatan. Mereka saling berbagi permasalahan sehari-hari yang mereka alami. Mereka juga saling mendukung dan membela temannya yang memiliki masalah. Ada beberapa siswa yang sering menjadi tempat curhat bagi temantemannya. Walaupun siswa laki-laki tidak terlalu mempermasalahkan relasi pertemanan dan persahabatan, namun mereka juga cenderung berkelompok dengan teman sebayanya yang memiliki kesamaan. Meskipun cenderung berkelompok, para siswa tetap berbaur dengan teman lainnya yang bukan termasuk kelompoknya.

Menurut Masters (dalam Ginting, 2015), teman sebaya merupakan faktor penting yang dapat menghindarkan anak dari gangguan kesehatan mental sehingga anak mampu mancapai kesejahteraannya. Berdasarkan penelitian yang dilakukan oleh Bokhorst, Sumter, dan Westernberg pada tahun 2010, didapatkan hasil bahwa remaja mendapatkan lebih banyak dukungan dari teman $(M=3,58)$ dibandingkan dengan dukungan dari orang tua $(M=3,56)$. Hal itu disebabkan karena remaja lebih banyak menghabiskan waktu bersama dengan teman sebayanya. Remaja juga akan merasa lebih nyaman dan lebih terbuka kepada teman sebayanya karena permasalahan yang dihadapi juga tidak jauh berbeda (Ginting, 2015). Berdasarkan penelitian yang dilakukan oleh Sasikala dan Cecil (2016) pada siswa Kelas XII, didapatkan hasil bahwa kelekatan teman sebaya berkorelasi positif dengan self-esteem dan psychological well-being. Berdasarkan penelitian Lucktong, Salisbury, dan Chamratrithirong (2017) menyatakan bahwa pengasuhan yang aman dan kelekatan teman sebaya berkaitan dengan psychological well-being pada remaja.

Dalam beberapa tahun, dukungan sosial sudah sering menjadi fokus penelitian karena dinilai dapat menjadi mekanisme proteksi dari luar yang penting terhadap 
kemungkinan hambatan, sehingga individu dapat mengatasi perubahan di dalam dan di luar lingkungan keluarga (Aragão, Vieira, Alves, dan Santos; Gonçalves, Pawlowsk, Bandeira, dan Piccinini dalam Leme, Prette, dan Coimbra, 2015). Beberapa penelitian telah berusaha untuk menunjukkan hubungan positif antara dukungan sosial dan well-being selama remaja (Casas dkk; Sarriera, Abs, Casas, \& Bedin, dalam Leme, Prette, \& Coimbra, 2015). Namun, belum banyak penelitian yang mengkaitkan antara dukungan sosial teman sebaya dengan psychological well-being pada remaja.

Penelitian ini hanya berfokus pada remaja awal karena remaja awal merupakan fase pertama pada masa remaja sehingga mereka mengalami perubahan yang signifikan dari masa kanak-kanak ke masa remaja. Transisi dari sekolah dasar ke sekolah menengah pertama terjadi bersamaan dengan sejumlah perubahan perkembangan lainnya (Santrock, 2012). Perubahan-perubahan tersebut mencakup hal-hal yang berkaitan dengan pubertas dan citra tubuh; munculnya pemikiran operasional formal; meningkatnya tanggung jawab dan menurunnya ketergantungan pada orang tua; memasuki struktur sekolah yang lebih besar dan impersonal; perubahan dari satu guru ke banyak guru serta perubahan kelompok teman sebaya yang kecil dan homogen menjadi kelompok teman sebaya yang lebih besar dan heterogen.

Dari uraian di atas dapat disimpulkan bahwa remaja yang mendapat dukungan sosial terutama dukungan dari teman sebaya akan lebih baik dalam mencapai psychological well-being. Seperti yang sudah dijelaskan sebelumnya bahwa dukungan sosial merupakan salah satu faktor yang dapat mempengaruhi psychological well-being. Peneliti berasumsi bahwa dukungan sosial dari teman sebaya dapat menjadi prediktor psychological well- being pada remaja. Oleh karena itu, hipotesis yang diajukan dalam penelitian ini adalah dukungan sosial teman sebaya dapat memprediksi psychological wellbeing pada remaja.

\section{Metode Penelitian}

Jenis penelitian

Penelitian ini menggunakan pendekatan kuantitatif dengan jenis korelasional.

\section{Waktu dan tempat penelitian}

Penelitian ini dilakukan pada tanggal 2-29 Januari 2019 di SMP IT Masjid Syuhada Yogyakarta.

\section{Subjek Penelitian}

Populasi penelitian ini adalah seluruh siswa SMP IT Masjid Syuhada Yogyakarta yang berjumlah 283 orang. Sampel penelitian ditentukan berdasarkan Tabel Krejcie dan Morgan (1970) yang berjumlah 162 orang. Pengambilan sampel menggunakan teknik probability sampling dengan jenis simple random sampling.

\section{Teknik pengumpulan data dan instrumen}

Teknik pengumpulan data dalam penelitian ini adalah menggunakan skala Psychological well-being dan skala Dukungan Sosial Teman Sebaya. Skala Psychological wellbeing disusun merujuk teori Ryff (2014) dengan enam dimensi psychological well-being, yaitu: (1) otonomi, yang berarti individu melihat dirinya hidup sesuai dengan keyakinannya sendiri; (2) penguasaan lingkungan, yang berarti seberapa baik individu mengelola situasi hidupnya: (3) pertumbuhan pribadi, yakni sejauhmana memanfaatkan bakat dan potensi yang ada pada dirinya: (4) hubungan positif dengan orang lain, yaitu Kedalaman hubungan yang dimiliki individu dengan orang lain atau orang-orang terdekat; (5) tujuan hidup, yaitu sejauh mana individu merasa hidupnya bermakna, memiliki tujuan, dan arah; dan (6) penerimaan diri yaitu pengetahuan dan penerimaan yang dimiliki individu tentang dirinya, termasuk kesadaran akan keterbatasan dirinya. Individu dapat dikatakan memiliki psychological well-being apabila memenuhi keenam dimensi tersebut. Jika individu hanya memenuhi 
beberapa dimensi saja, maka individu tersebut belum dapat dikatakan memenuhi psychological well-being.

Skala Dukungan Sosial Teman

Sebaya terdiri dari 4 aspek, yaitu (1) dukungan nyata, yang berarti bantuan yang diberikan secara langsung yang bersifat fasilitas atau materi; (2) dukungan kepemilikan, yakni perasaan memiliki seseorang yang dapat memberikan rasa aman dan nyaman pada saat dirinya menghadapi kesulitan; (3) dukungan harga diri, yaitu individu mendapatkan penghargaan positif dari orang lain yang berkaitan dengan ketrampilan dan kemampuannya; dan (4) dukungan penilaian, yang berarti individu merasa dapat bergantung pada lingkungan untuk mendapatkan petunjuk berupa nasihat, saran ataupun umpan balik mengenai apa yangsebaiknya dilakukan. Dukungan sosial dapat terbentuk apabila dukungan yang diberikan berupa dukungan yang nyata, dukungan kepemilikan, dukungan harga diri, dan dukungan penilaian.

\section{Teknik Analisis data}

Teknik analisis data yang digunakan dalam penelitian ini meliputi analisis deskriptif dan uji prasyarat analisis data yang terdiri dari uji normalitas dan uji linearitas; serta uji hipotesis statistik.

\section{Analisis Deskriptif}

Analisis deskriptif digunakan untuk menjelaskan secara umum hasil penelitian yang dilakukan untuk mengkategorisasi tingkatan pada variabel $\mathrm{X}$ dan Y. Data yang diperoleh dari Skala Psycbological well-being dan Skala Dukungan Sosial Teman Sebaya masih berupa data ordinal yang terdiri dari kategori sangat sesuai (nilai empat), sesuai (nilai 3), tidak sesuai (nilai 2), dan sangat tidak sesuai (nilai 1). Kategorisasi tersebut akan diubah ke dalam data interval dengan perhitungan manual.

Tabel 1. Norma Kategorisasi

Kategorisasi Rumus

\begin{tabular}{ll}
\hline Sangat Tinggi & $\mathrm{X}>\mu+1.5 \sigma$ \\
Tinggi & $\mu+0.5 \sigma<\mathrm{X} \leq \mu+$ \\
& $1.5 \sigma$ \\
Sedang & $\mu-0.5 \sigma<\mathrm{X} \leq \mu+0.5 \sigma$ \\
Rendah & $\mu-1.5 \sigma<\mathrm{X} \leq \mu-0.5 \sigma$ \\
Sangat Rendah & $\mathrm{X} \leq \mu-1,5 \sigma$ \\
\hline
\end{tabular}

Keterangan :

$\mu \quad:$ mean teoritik

$\sigma \quad$ : satuan standar deviasi

Pada penelitian ini dilakukan uji normalitas dan linieritas sebagai prasyarat analisis.

1. Uji Normalitas

Uji normalitas digunakan untuk mengetahui apakah data berdistribusi normal atau tidak. Uji normalitas menggunakan uji Kolmogorov-Smirnov dengan $(\alpha)=0,05$ dengan bantuan program SPSS for Windows. Data yang berdistribusi normal memiliki $\alpha>0.05$ (Ghozali,2018).

\section{Uji Linieritas}

Uji linearitas digunakan untuk melihat apakah spesifikasi model yang digunakan sudah benar atau tidak. Uji linearitas bertujuan untuk mengetahui hubungan antara dua variabel linear secara signifikan atau tidak. Kedua variabel dikatakan linear apabila memiliki $\alpha>0.05$ (Ghozali, 2018).

\section{Uji hipotesis}

Uji hipotesis menggunakan teknik analisis regresi linear dengan bantuan program SPSS for Windows. Teknik analisis regresi linear dipilih karena penelitian ini bertujuan untuk memprediksi atau meramalkan nilai variabel kriterium berdasarkan nilai variabel prediktor yang diketahui (Gujarati dalam Ghozali, 2018). Variabel yang meramalkan disebut variabel prediktor (X) yang dalam penelitian ini adalah dukungan sosial teman sebaya, sedangkan variabel yang diramalkan disebut variabel kriterium $(\mathrm{Y})$ yang dalam penelitian ini adalah psychological well-being. Hubungan antara variabel $\mathrm{X}$ dan $\mathrm{Y}$ bersifat searah dan tidak dapat saling mempengaruhi, artinya 
variabel $\mathrm{X}$ yang menjadi prediktor bagi variabel $\mathrm{Y}$, dan variabel $\mathrm{Y}$ tidak bisa menjadi prediktor bagi variabel $\mathrm{X}$.

\section{Hasil Penelitian dan Pembahasan}

Berdasarkan hasil penelitian, dukungan sosial teman sebaya dapat menjadi prediktor bagi psychological well-being pada remaja. Hal ini menunjukkan bahwa hipotesis terbukti. Hasil penelitian ini sejalan dengan penelitian Ginting (2015) yaitu dukungan sosial orangtua, pengasuh panti, dan teman sebaya dapat secara bersama- sama menjadi prediktor terhadap kesejahteraan psikologis pada remaja yang tinggal di panti asuhan di Boyolali.

Remaja yang mendapatkan dukungan sosial dari teman sebayanya akan merasa disayangi, diperhatikan, dan dipedulikan oleh teman sebayanya (Ginting, 2015). Dengan begitu, remaja akan mengembangkan sikap yang positif dan memiliki psychological well-being yang tinggi. Remaja yang memiliki psychological well-being akan dapat berfungsi secara positif dalam mencapai aktualisasi diri dan menjalankan tahapan perkembangannya. Sebaliknya, remaja yang tidak mendapatkan dukungan sosial dari teman sebayanya akan merasa tidak berguna, tidak ada seseorang yang peduli dengannya, dan melihat dirinya secara negatif. Dengan begitu, remaja tidak dapat berkembang secara positif dan tidak dapat mengembangkan dirinya sehingga memiliki psychological well-being yang rendah. Remaja yang memiliki psychological well-being yang rendah akan kesulitan memilah pengaruh buruk dari lingkungan dan menyebabkan munculnya kenakalan remaja.

Hasil penelitian menunjukkan bahwa tingkat psychological well-being termasuk dalam kategori sedang. Hal itu dikarenakan dukungan sosial yang didapatkan dari teman sebaya juga termasuk dalam kategori sedang. Diketahui paling banyak siswa memiliki tingkat psychological well-being pada kategori sedang $(174<\mathrm{X} \leq 192)$ dengan jumlah siswa sebanyak 63 siswa $(38.89 \%)$. Sejalan dengan tingkat dukungan sosial teman sebaya yang didapatkan juga berada pada kategori sedang $(44<\mathrm{X} \leq 51)$ dengan jumlah siswa sebanyak 84 siswa $(51,85 \%)$. Hanya 9 siswa (5,56\%) yang memiliki tingkat psychological well-being pada kategori sangat tinggi dan 11 siswa $(6,79 \%)$ yang mendapatkan dukungan sosial kategori sangat tinggi. Hal itu menunjukkan bahwa apabila remaja mendapatkan dukungan sosial dari teman sebaya, maka remaja akan memiliki tingkat psychological well-being yang tinggi. Sebaliknya, remaja yang tidak mendapatkan dukungan sosial dari teman sebaya maka remaja akan memiliki tingkat psychological well-being yang rendah. Dukungan sosial teman sebaya dapat membantu remaja dalam mengembangkan sikap yang positif hingga akhirnya remaja dapat mencapai aktualisasi diri.

Dilihat dari hasil analisis, variabel Dukungan Sosial Teman Sebaya berpengaruh positif terhadap variabel psychological well-being dengan memberikan sumbangsih sebesar $42,4 \%$. Adapun sebesar $57,6 \%$ dijelaskan oleh variabel lain di luar Dukungan Sosial Teman Sebaya. Hal itu berarti bahwa ada pengaruh dukungan sosial teman sebaya terhadap psychological well-being pada remaja. Dukungan sosial teman sebaya memberikan pengaruh sebesar $42,4 \%$ bagi terbentuknya psychological well-being pada remaja. Dengan kata lain, salah satu hal yang dapat dilakukan agar remaja memiliki psychological well-being yang baik adalah dengan memberikan dukungan sosial teman sebaya. Remaja dapat memperoleh dukungan sosial dari teman sebayanya apabila ia memiliki teman dekat. Teman dekat cenderung akan memberikan dukungan sosial kepada temannya. Remaja yang tidak memiliki teman dekat cenderung tidak memperoleh dukungan sosial dari teman sebaya. Sesuai dengan pendapat Krammer (dalam Himmah, 2015) bahwa individu yang tidak memiliki teman dekat cenderung mempunyai psychological well-being yang rendah. 
Berdasarkan hasil penelitian ini juga diketahui bahwa terdapat $57,6 \%$ faktor lain yang dapat mempengaruhi psychological wellbeing pada remaja selain dukungan sosial teman sebaya. Hal itu disebabkan karena dukungan sosial teman sebaya bukanlah faktor utama dalam menentukan tingkat psychological well-being pada remaja, masih ada faktor-faktor lain seperti faktor demografis (usia, jenis kelamin, kelas sosial ekonomi, budaya), faktor kepribadian, dan faktor religiusitas (Himmah, 2015). Individu di usia yang berbeda akan memiliki tingkat psychological well-being yang berbeda pula karena berkaitan dengan tingkat pemahaman individu tersebut dalam memaknai sesuatu. Jenis kelamin akan membentuk perilaku tertentu, dimana perilaku laki-laki dan perempuan berbeda yang akhirnya akan mempengaruhi tingkat psychological well-being. Budaya mempengaruhi tingkat psychological well-being dimana pada budaya timur lebih tinggi pada dimensi yang berorientasi pada orang lain, sedangkan budaya barat lebih tinggi pada dimensi yang berorientasi pada diri sendiri. Individu yang memiliki kepribadian tertentu akan berpengaruh juga pada dimensi tertentu. Individu yang memiliki tingkat religiusitas yang tinggi akan memiliki tingkat psychological well-being yang tinggi pula.

Hasil penelitian ini sejalan dengan Teori psychological well-being (Ryff \& Keyes, 1995) yang menyatakan bahwa dukungan sosial merupakan salah satu faktor penting dalam psychological well-being perempuan. Meskipun penelitian ini hanya melibatkan dukungan sosial dari teman sebaya dan dilakukan kepada subjek laki-laki dan perempuan, namun hasil penelitian ini masih relevan dengan teori psychological wellbeing dari Ryff dan Keyes (1995). Dukungan sosial dapat berasal dari orang-orang penting yang dekat (significant others) bagi individu yang membutuhkan bantuan seperti guru dan teman-teman (Johnson \& Johnson dalam Adicondro \& Purnamasari, 2011). Sesuai dengan Teori Santrock (2012) bahwa remaja lebih banyak berinteraksi dengan teman sebaya dibandingkan dengan orangtua, sehingga remaja yang tidak memiliki teman dekat cenderung tidak mendapatkan dukungan sosial dari teman sebaya.

Skor dimensi tertinggi adalah dimensi hubungan yang positif dengan orang lain sebesar $35,77 \%$. Skor dimensi terendah adalah dimensi tujuan hidup sebesar 9,27\%. Hasil ini sesuai dengan tugas-tugas perkembangan remaja menurut Havighurst (dalam Gunarsa \& Gunarsa dalam Lestari, 2016), yaitu remaja akan menjalin hubungan yang lebih matang dengan teman sebaya, baik laki-laki maupun perempuan dan mampu berperan secara sosial sesuai dengan peran jenisnya. Pada masa remaja, kesadaran sosial akan semakin tinggi dan menyebabkan munculnya tekanan sosial di setiap harinya (Ginting, 2015). Dengan adanya psychological well-being, remaja akan dapat menolak tekanantekanan sosial tersebut.

Dimensi tujuan hidup memiliki skor yang rendah karena remaja awal belum berorientasi untuk mencapai tujuan-tujuan dalam hidupnya. Pada remaja awal kebutuhan intimasi juga semakin tinggi (Sullivan dalam Santrock, 2012). Dengan adanya sahabat, remaja tidak akan merasa terlalu tertekan dengan perubahan dari sekolah dasar ke sekolah menengah. Sahabat membantu remaja dalam menyesuaikan diri di lingkungan yang lebih luas. Dukungan sosial dari teman sebaya akan membuat remaja merasa aman dan nyaman. Ketika remaja telah merasakan kenyamanan, merasa disayangi dan dihargai, ia akan dapat mencapai aktualisasi dirinya sehingga tujuan hidupnya akan tercapai.

\section{Simpulan dan Saran}

\section{Simpulan}

Berdasarkan hasil penelitian, diketahui bahwa terdapat hubungan yang positif antara dukungan sosial teman sebaya dengan psychological well-being pada remaja. Dukungan sosial teman sebaya dapat menjadi prediktor adanya 
psychological well-being pada remaja. Hal itu berarti, remaja yang mendapatkan dukungan sosial dari teman sebaya akan memiliki tingkat psychological well-being yang tinggi. Sedangkan remaja yang tidak mendapatkan dukungan sosial dari teman sebaya akan memiliki tingkat psychological well-being yang rendah.

\section{Saran}

Berdasarkan kesimpulan yang telah disebutkan sebelumnya, peneliti akan memberikan saran kepada beberapa pihak di antaranya adalah:

1. Bagi Remaja

Remaja perlu meningkatkan kesadaran akan tujuan hidup, menyusun cara-cara untuk mencapai tujuan hidup tersebut, dan yakin akan tujuan hidupnya; perlu mempertahankan hubungan yang baik dengan orang lain, peduli terhadap kesejahteraan orang lain, menunjukkan perasaan kasih sayang kepada orang lain, dan dapat bersikap terbuka dengan orang lain.

2. Guru BK perlu meningkatkan kesadaran siswa tentang tujuan hidup, mengajarkan membuat rancangan tujuan hidup dan cara-cara untuk mencapai tujuan hidup tersebut; perlu memberikan pemahaman kepada siswa untuk mempertahankan hubungan yang baik dengan orang lain, peduli terhadap kesejahteraan orang lain, dan dapat bersikap terbuka dengan orang lain.

3. Bagi Orangtua

Orangtua perlu meningkatkan kesadaran anak tentang kebermaknaan hidup dan keyakinan dalam mencapai tujuan hidup; perlu memberikan pemahaman kepada anak untuk mempertahankan hubungan yang saling terpercaya dengan orang lain dan mampu berempati kepada orang lain.

4. Peneliti Selanjutnya

Peneliti selanjutnya sebaiknya memperluas batasan wilayah generalisasi pada remaja akhir karena penelitian ini hanya dapat digeneralisasikan pada remaja awal

\section{Daftar Pustaka}

Adicondro, N., \& Alfi Purnamasari. (2011). Efikasi diri, dukungan sosial keluarga, dan self regulated learning pada siswa kelas VIII. Jurnal Humanitas, 8 (1), 17-27.

Batubara, A. (2017). Hubungan antara religiusitas dengan psychological wellbeing ditinjau dari Big Five Personality pada siswa SMA Negeri 6 Binjai. Jurnal Al-Irsyad, 8 (1), 31-41.

Ginting, D.C.E. (2015). Dukungan sosial orangtua, pengasuh panti, dan teman sebaya sebagai prediktor terhadap kesejahteraan psikologis pada remaja yang tinggal di Panti Asuhan di Boyolali. Skripsi. Fakultas Psikologi. Universitas Kristen Satya Wacana Salatiga.

Himmah, $F(2015)$. Hubungan religiusitas dengan kesejahteraan psikologis. Skripsi. Fakultas Psikologi dan Kesehatan. Universitas Islam Negeri Sunan Ampel Surabaya.

Indrawati, Triana. (2017). Peranan kecerdasan emosi dan dukungan sosial terhdap kesejahteraan psikologis siswa SMP Terbuka di Cirebon. Jurnal Edukasia Islamika, 2, (1), 77-103.

Leme, V.B.R., Z.A.P.D.Prette., \& Coimbra, S. (2015). Social skills, social support and well-being in adolescents of different family configurations. Journal of Paideia, 25(60),9-18.

Lestari, V. (2016). Hubungan antara dukungan sosial orangtua dengan penyesuaian diri remaja dengan 
orangtua bercerai. Skripsi. Fakultas Psikologi. Universitas Sanata Dharma Yogyakarta.

Lucktong, A., Salisbury. T.T., \& Chamratrithirong, A. (2017). The impact of parental, peer and school attachment on the psychological well- being of early adolescents in Thailand. International Journal of Adolescence and Youth, ISSN: 02673843, 1-16.

Murtiningtyas, R. A. (2017). Hubungan antara self-esteem dengan psychological well-being pada remaja. Skripsi. Program Studi Psikologi, Jurusan Psikologi, Universitas Muhammadiyah Surakarta.

Putra, F. \& Ramdani. (2014). Ketercapaian tugas-tugas perkembangan remaja dan pendidikan seksual pada remaja. Jurnal Konseling dan Pendidikan, 2 (3), 37-41.

Ryff, C.D. (1989). Happiness is everything, or is it? Explorations or the meaning of psychological well-being. Journal of Personality and Social Psychology, 57(6). 1069-1081.

Ryff, C.D \& Keyes, L.M. (1995). The structure of psychological well-being revisited. Journal of Personality and Social Psychology, 69 (4), 719-727.

Santrock, J.W. (2007). Perkembangan Anak. Edisi kesebelas. Jakarta: PT. Erlangga.

Santrock, J.W. (2012). Perkembangan Masa Hidup (diterjemahkan oleh Benedictine Wisdyasinta), Edisi ketigabelas. Jakarta: Erlangga.

Seymour, N. (2015). Psychological well-being in adolescents: planning towards and thinking about the future. Dissertation in Clinical Psychology,
Royal Holloway. University of London.

Sucahyo, N. (2017). Kekerasan bersenjata tajam di kalangan remaja yogya kian mempribatinkan. Diunduh pada tanggal 18 Oktober 2018 dari www.voaindonesia.com 